\title{
Translation, Diplomacy and Espionage: New Insights into James Mabbe's Career $^{1}$
}

\author{
José María Pérez Fernández \\ University of Granada
}

James Mabbe's claim to fame rests on his translations of Spanish classics of Golden Age prose fiction, namely Mateo Alemán's Guzmán de Alfarache (The Rogue, 1622), La Celestina (The Spanish Bawd, 1631), and his rendering of some of Cervantes's Novelas Ejemplares (Exemplarie Novells, 1640). The Rogue was Mabbe's first published translation and as we shall see it soon established his reputation as a translator. It was also among his most successful texts, going through four different reprints only in the first half of the seventeenth century $(1623,1630,1634$, and 1640), and enjoying a steady demand afterwards. The excellence of his prose has indeed granted Mabbe a place of honour in the English canon, and The Rogue is generally accounted as one of the texts that constitute the seedbed for the subsequent development of the English novel. ${ }^{2}$ As an active promoter of Spanish literature Mabbe is also regarded as one of the founders of English Hispanism. Without any doubt he displayed as much foresight as he did critical perception in his choice of texts, and although his production and his career have not received all the attention they deserve, these literary translations have given him the sort of visibility that many of his fellow translators never enjoyed.

Born in 1572, James Mabbe was from his youth attached to Magdalen College in Oxford, where he was a Demy from 1586-94 and a Fellow from 1594-1633. ${ }^{3}$ His diplomatic activity facilitated his first known direct contact with Spain, which he visited in 1611 as a member of an English legation led by Sir John Digby. He also had important connections within the networks established between the publishing industry in London and Oxford scholars. He was among the authors who provided introductory poems for Shakespeare's First Folio and John Florio's Italian dictionary, Queen Anna's New World of Words, both of them published, like The Rogue, by Edward Blount. A discerning and prolific publisher, well attuned to the new volumes that were coming out of other European presses, and with an excellent instinct for works that would eventually become classics-a feature he shared with Mabbe-Blount was responsible for the production and distribution of grammars, dictionaries, and translations-including Florio's Montaigne or Shelton's Don Quixote - that contributed to internationalize the domestic literary scene of early seventeenthcentury London. ${ }^{4}$ Mabbe's transactions with Blount thus drew him into a constellation of important cultural agents with a keen interest in other European vernaculars. These groups in turn also branched out towards networks of political patronage that comprehended diplomats, spies and other agents of exchange. A bird's eye view of Mabbe's intellectual background in Oxford, his acquaintance with court intrigues both in London and Madrid, and the activities of his patrons will contribute to throw new light upon his output, both literary and otherwise.

\footnotetext{
1 This essay is a previous, longer version of an article which has been accepted for publication in Translation and Literature (forthcoming in volume 23, part 1, Feb/March, 2014). I am grateful to the editors and publishers of Translation and Literature for allowing the publication of this previous version in our institutional repository.

2 On The Rogue, the picaresque in general, and its relation to the English novel, see Michael McKeon's The Origins of the English Novel. 1600 - 1740 (Baltimore \& London: The Johns Hopkins University Press, 2002, pp. 96-100). Also J. R. Yamamoto-Wilson, 'James Mabbe's Achievement in his Translation of Gurmán de Alfarache', Translation and Literature, 8 (1999), 137-156.

3 "Demy" is Magdalen College's term for a scholar: the noun derives from the fact that its founder decreed that Magdalen scholars should receive half the allowance of the Fellows. I am grateful to Robin Darwall-Smith, archivist of Magdalen College, and James Fishwick, its librarian, for their assistance during the research that led to the publication of this article. This research was also made possible by Edward Wilson-Lee, of Sidney Sussex College, Elizabeth Drayson and Elsa Strietman, of Murray Edwards College, and Louise Haywood, of the Spanish and Portuguese Department, all of whom kindly extended their hospitality, and invitations as research and visiting scholar during different periods at the University of Cambridge.

${ }^{4}$ See Gary Taylor, "Edward Blount", DNB. For more details on Blount-whose importance for the literature of this period calls for a monograph—see Leah Scragg's 'Edward Blount and the History of Lylian Criticism', Review of English Studies, 46(1995), 1-10, and above all 'Edward Blount and the Prefatory Material to the First Folio of Shakespeare', Bulletin of the Jobn Rylands University Library of Manchester, 79(1997), 117-26. A more recent account of Mabbe's literary associates, and his possible connection with Shakespeare, can be found in John Yamamoto-Wilson's 'Mabbe's Maybes: A Stuart Hispanist in Context', Translation and Literature, 2(2012) 319-42.
} 
Mabbe's indisputable importance as a translator of early modern Spanish prose fiction has eclipsed the rest of his production. By contrast, his translations of religious and political texts are less known: they have never been issued in modern editions—one of them never saw print—and virtually nothing has been published in extenso about them. An account of the contexts within which these texts were produced will facilitate a more accurate understanding not just of James Mabbe's literary translations, but of his career as a whole. ${ }^{5}$ This should in turn open up new paths for research into unexplored corners of Anglo-Spanish relations during this period. As recently published essays by Alexander Samson and Barbara Fuchs have demonstrated, there are important political dimensions to English translations from Spanish literature during the sixteenth and seventeenth centuries. ${ }^{6}$ Certain aspects of Anglo-Spanish political and cultural relations in particular constitute undercurrents that extend well beyond the literature produced around prominent events like Phillip II's period as king consort after his marriage to Mary Tudor, the Armada episode, or the Spanish Match. In this regard, an account of Mabbe's output as a translator of political and religious treatises should lead to a re-evaluation of the impact of Spanish political thought upon late sixteenth- and early seventeenth-century England. Mabbe's texts were preceded by a series of English translations from Spanish political treatises on counselling and counsellors that still require further study. These included, among others, $A$ very briefe and profitable treatise declaring bowe many counsells, and what maner of counselers a prince that will gouerne well ought to haue (London: William Seres, 1570,STC (2nd ed.), 11488), Thomas Blundeville's abridged translation (from the Italian version of Alfonso de Ulloa) of Fadrique Furió Ceriol's El Concejo y Consejeros del Principe (Antwerp: Martin Nutius, 1559), and The counseller: a treatise of counsels and counsellers of princes (London: J. Wolfe and J. Charlewood, 1589,STC (2nd ed.), 10753), John Thorius' translation of Bartolomeu Felipe's Tractado del conseio y de los consejeros de los Principes (Coimbra: Antonio de Mariz, 1584).

Beyond Anglo-Spanish relations, Mabbe's extensive connections, both domestic and international, turn him into an excellent case study that illustrates the role played by translation, diplomacy and espionage in the weaving of the cultural, political and religious cartography of Europe as the entire continent found itself increasingly embroiled in the controversies and conflicts that led to the Thirty Years' War. In other words, a comprehensive approach to his production and his relations will display him as the agent of exchange that he actually was-an epitome of the numerous individuals like him that crisscrossed early modern Europe and contributed to stitch the continental patchwork together. After a concise account of his published religious and political texts, this article will proceed by looking at Mabbe's Oxford background, with a focus on the members of a group that I shall call the Magdalen College Linguists. Their religious and political connections will then lead to a survey of Mabbe's allegiances through an examination of his published volumes, and also of some primary documents, under the light shed by his patrons and dedicatees-all of which will finally take us back to a reconsideration of his textual output.

The first of Mabbe's non-literary translations was Devout Contemplations expressed in Two and Fortie Sermons upon all ye Quadragesimall Gospels (London: Adam Islip, 1629, ESTC (2nd ed.) / 11126), his rendering of Fray Cristóbal de Fonseca's Discurso para todos los evangelios de la Cuaresma (Madrid, 1614).7 Issued in 1629, it was Mabbe's second published translation after the success of The Rogue.

\footnotetext{
${ }^{5}$ In his recent survey on Mabbe, Yamamoto-Wilson (2012, 335-336) resorts to quotations from Christian Policie to support his view of Mabbe as driven by what he describes as an agenda of social reform and concern for the poor-he claims that 'If Mabbe was a crusader for a cause, surely it was this' (p. 333)—even of political subversion (p. 336). While I am not fully persuaded by this view, and while I also disagree on some points with Yamamoto-Wilson's insights into 'Mabbe's Maybes', I still think that his article is a very perceptive account that contributes to a better understanding of Mabbe's achievements. I am most grateful too for the comments he provided after reading a previous version of the present article.

${ }^{6}$ The subject of Anglo-Spanish literary relations was substantially reviewed through a few case studies in a monograph issue of the Journal of Medieval and Early Modern Studies 39(2009). In that issue Alexander Samson's "'A Fine Romance": Anglo-Spanish Relations in the Sixteenth Century' provides a survey of the political and cultural relations between the two countries. Barbara Fuch's 'Pirating Spain: Jonson's Commendatory Poetry and the Translation of Empire' (Modern Philology, 99 (2002), 341-356) focused on Jonson's poem in praise of Mabbe's translation of Gurmán de Alfarache. This poem has been recently published as part of The Cambridge Edition of the Works of Ben Jonson (ed. by D. Bevington, M. Butler and I. Donaldson, vol. 5, 1616-1625, Cambridge University Press, 2012, p. 610), edited and annotated by Colin Burrow.

7 On Devout Contemplations, see Yamamoto-Wilson, 2012, 337-39.
} 
The volume consisted of a collection of sermons on the Lent Gospels: this type of compilations abounded in the Spanish book market, where they had become domestic bestsellers. They were also in some demand in the rest of Europe, where they circulated in translations into the main vernaculars. ${ }^{8}$ Mabbe's English version was part of this international demand, and although it only went through a single edition, it was widely distributed: according to data provided by the British Library's English Short Title Catalogue, twenty-nine copies remain in British libraries-with eight more copies still extant in North American collections.

If Devout Contemplations illustrates Mabbe's religious agenda, the translation that he published in 1632 (just one year after The Spanish Bawd went through the printing press) reveals his political interests, and those of his patrons. In that year he published his rendering of Fray Juan de Santa Maria's República y policia cristiana para reyes y principes (Madrid, 1615). This translation was first issued under two different titles, one of which was Christian Policie: or, The Christian Commonwealth. Published for the good of Kings, and Princes, and such as are in authoritie vnder them, and trusted with State Affaires (London: Thomas Harper for Edward Blount, 1632, STC 14830.7). In the same year Thomas Harper printed another issue for Richard Collins, with a different title-page and another title too, Policie vnveiled: vvherein may be learned, the order of true policie in kingdomes, and common-wealths: the matters of justice, and governement; the addresses, maxims, and reasons of state: the science of governing well a people: and where the subject may learne true obedience unto their kings, princes, and soveraignes.(STC (2nd ed.), 14831a).In contrast with the former, this title page provides more information about the translator-who is identified as 'I.M. of Magdalen Hall in Oxford'-as it also elaborates in more detail on its contents, the political nature, and the purposes of the treatise. In spite of their differences these two title pages cover the same edition, which is dedicated by Edward Blount to the influential courtier and diplomat James Hay, Earl of Carlisle. A second reprint appeared in 1634, also titled Policie vnveiled, but with a slightly different title page featuring Humphrey Moseley 9 as the publisher this time (STC (2nd ed.), 14832, see image 3).

Its third reprint was also issued by Humphrey Moseley, in 1637, with a more elaborately ornamented title page, and a shorter title which identifies Mabbe not as the translator, but as its author: Policie Vnveiled, Or Maximes and Reasons of State. Written by I.M. of Magdalen Colledge in Oxford (STC (2nd ed.) 14832a, see image 4). This reprint reproduces the same dedicatory epistle, also signed by Blount, which is on this occasion addressed not to Hay, but to Sir Dudley Carleton. All of these three individuals, Blount, Hay and Carleton, were dead by 1637-Blount and Carleton had both passed away in 1632, and Hay had just died one year before, in 1636. In the middle of intense domestic political fray, and under Charles I's personal rule, when England was also engulfed in the European political, religious and military turmoil that was the Thirty-Years' War, it would appear that both the publisher-and I.M. of Magdalen Colledge as the 'author'-were adopting a cautious strategy by dedicating a political treatise penned by the chaplain of the most Catholic king of Spain to Hay and Carleton. Both had been well-known promoters of anti-Habsburg, Protestant policies, both had also enjoyed a good reputation as diplomats with enough political experience abroad, but at the same time both had also been deemed capable of building bridges across the religious and the political divides when necessary. Carleton tried to keep a balance between personal autocratic rule by Charles I-which he never failed to defend - the need for counsel, and the traditional roles of Parliament. Hay has been described as 'one of the few staunch Protestants at the royal court who could effectively negotiate with Roman Catholics from other countries.' The fact that they were now safely dead might have been considered a plus—or a safeguard of sorts—-for those involved in the production and distribution of the volume, who thus shunned any explicit allegiance to living politicians..$^{10}$

\footnotetext{
${ }^{8}$ An Italian translation by Pietro Maria Marchetti, the Discorsi scritturali e morali sopre gli evangeli..., was published in Brescia in 1617.Seealso Pablo Jauralde Pou 'El estilo cervantino' in Anthony Close, et al. Cervantes (Alcalá de Henares: Centro de Estudios Cervantinos, 1995, 137-154, p. 154).

${ }^{9}$ Moseley had begun his independent publishing career around 1633-34, and in spite of his openly royalist sympathies he continued to thrive through the Civil War, and well into the Restoration. During these latter periods he enjoyed a reputation as one of the best literary publishers in London. On Moseley's status and reputation during the Civil War and the Restoration see Lois Potter, Secret Rites and Secret Writing. Royalist Literature, 1641-1660. (Cambridge: Cambridge University Press, 1989, 20).

${ }_{10}$ On Carleton and Hay, see their respective entries (byL.J. Reeve, on the former, and Schreiber, on the latter) in the DNB.
} 
Policie Vnveiled was thus proving to be a moderate editorial success that continued to be popular well into Cromwell's rule-in spite of being a political treatise penned by a Spanish Catholic. The late Kevin Sharpe frequently quoted from this translation to illustrate his splendid volume on English political culture during the first half of the seventeenth century (Remapping Early Modern England, Cambridge, 2000), and he also used it in his monograph on The Personal Rule of Charles I (New Haven \& London, 1992) to exemplify current role models for court politics. This clearly hints to the understudied importance of Mabbe's activities as a translator of political and religious treatises, and to the relevance of this volume in particular. Policie V nveiled was reprinted for the fifth and last time in 1650, also by Moseley. In this edition, produced about eight years after Mabbe's death $c a$. 1642, the dedication of the volume reverted to James Hay, and the title-framed within another lavishly ornamented engraving - changed in significant ways: Policy vnveiled, or Maximes of state. Done into English by the translator of Gusman the Spanish Rogue (ESTC citation no. R19477,see image 5). This new reprint proves, on one hand, the lasting demand for a volume of this kind in this most relevant of periods within English political and religious history; and on the other the evolution of the title pages also demonstrates the growing reputation of Mabbe as a translator-or rather, the reputation of The Rogue. Mabbe had evolved from anonymity in 1632_or from the mere use of his initials and the reference to Magdalen, in the first two editions- to his appearance as the author of the book itself in 1637, only to have his name eventually obliterated in the last reprint, where he has become just 'the translator of Gusman, the Spanish Rogue'. The fame of Mabbe's The Rogue had finally overshadowed his own name, as well as the rest of his production, and his Englished picaro could now be used to entice readers to purchase other volumes. The fact that the publisher of the 1650 edition decided to promote what he described as a collection of Maximes of State under cover of the reputation — literary, and otherwise — of a famous Spanish rogue is not devoid of a certain irony-maybe unintended, but then, maybe not.

$\cos$

Mabbe's lifelong attachment to Magdalen College links him with a group of linguists, translators and diplomats, all of whom were educated and / or spent at least part of their careers in close attachment to this particular institution. They illustrate not just the personal relations that Mabbe established in Oxford, but also the sort of intellectual and religious background that he experienced, in particular as a young student, and early in his career. One of these acquaintances was the rhetorician Charles Butler (1560 - 1647), who obtained his MA in 1587, when Mabbe was already a Demy in Magdalen. Since it was usual for senior students to lecture the younger members of their college, Mabbe may have been one of Butler's pupils. Among Butler's most successful publications was a volume titled Rhetoricae libri duo: quorum prior de tropis \& figuris, posterior de voce \& gestu praecipit which has been described as "a pared-down version of the Rhetorica of Talaeus, who was a colleague of and collaborator with Ramus". ${ }^{11}$ Proof that Mabbe was acquainted with Butler's work is the blurb he wrote for the 1621 and 1629 editions of his Rhetoricae libri duo, where he recommends the volume based, inter alia, on the praise bestowed upon it by John Brinsley's Ludus Literarius: or, The Grammar Schole (London: Thomas Man, 1612, STC (2nd ed.), 3768), where the latter recommended the use of Butler's rhetoric, since it was more accessible to students than Talaeus:

\section{I.M. Lectori.}

$\mathrm{Si}$ in Authoris operisve laudem, (studiose Lector), multorum hic, pro more, suffragia requiras; instar multorum sit hoc unum literati illius, \&, ob exquisitam docendi methodum, de bonis litteris optime meriti, Magistri Ioannis Brinsley: cujus in suo LVDO LITERARIO, or The Grammar Schoole, Cap. 16. Haec sunt verba: In stead of Talaeus, you may use $\mathrm{M}^{\mathrm{r}}$ Butlers Rhetoricke of Magdalens in Oxford; being far more easie to bee learned of

\footnotetext{
11 Victor W. Cook, 'Charles Butler (ca. 1560 - 29 March 1647)', in Dictionary of Literary Biography, vol. 236. British Rhetoricians and Logicians, 1500, 1660. First Series. Ed. by Edward A. Malone. (London: Buccoli Clark Layman, 2001), 81-90, p. 81. The first edition of Butler's rhetoric was published under the title Rameae Rhetoricae Libri duo in vsum scholarum (Oxford: Joseph Barnes, 1597, STC (2nd ed.), 4196.5). Butler 'was highly instrumental in spreading the ideas of Pierre de la Ramée and Ramus's colaborator, Talaeus, in Britain by means of his preparatory texbooks.' (Cook, ibid., q.v. for further details on Butler)
} 
Schollars, and also supplying very many things wanting in Talaeus: yea the use and benefit will be found to be farre aboue all, that euer haue beene written to the same... For the figures belonging to Poetry, and for rules of the Quantity of syllables, short and very plaine, see Butlers Rhetoricke. ${ }^{12}$

Although from a previous generation, Laurence Humphrey $(1527$ - 1589) is particularly relevant as the author of the Interpretatio linguarum: seu de ratione convertendi et explicandi autores tam sacros quam prophanos (Basle: H. Frobenius \& N. Episcopius, 1559), a treatise on translation prepared and published during its author's Marian exile in Switzerland whose third book constitutes what is probably the first attempt to build up an early canon of eminent English translators. Humphrey also translated three dialogues attributed to Origen, which were published in 1571 by the great humanist printer Johannes Oporinus as part of the latter's edition of Origensis opera. Oporinus had also published a few years before the Epistola de Graecis litteris et Homeri lectione et imitatione (1558), Humphrey's contribution to methods for the interpretation of Greek literature in general, and of Homer in particular. Humphrey put all this expertise on classical and scriptural languages to good use through the production of texts that contributed to legitimize a certain branch of early modern political thought: his translation of Philo of Alexandria's De nobilitate-published by Oporinus in 1560as an appendix to Humphrey's own Optimates, sive de nobilitate - influenced Sir Thomas Smith's De republica anglorum..$^{13}$ By writing in Latin, and using Oporinus as his publisher, Humphrey was obviously seeking a transnational European readership for his volumes. Some of his works were deemed sufficiently relevant for a domestic audience, and were also translated into English. ${ }^{14}$ His widespread international connections turned Humphrey into a useful link between English Protestantism and its European counterparts. After Mary Tudor's death he returned to Oxford in 1560, where he became President of Magdalen College in 1561, an office he held until his death in 1589. He put his pen at the service of Anglican anti-Catholic propaganda during the 1580s, and although during his early years as President he proved to be more radical in his Protestant zeal than Elizabeth's settlement required — or was ready to tolerate-towards the end of his life he became a mainstream conformist. Overall, Humphrey's career prefigures the close relations between translation, humanist philology, international relations, religious doctrine and political thought that also underlie Mabbe's career a generation later.

The 1580s and early 1590s were also the years when international scholars like the Spanish Protestant exile Antonio del Corro, or the Italian Alberico Gentili lectured in Oxford. Whereas the former complemented his activities as a lecturer in divinity with his composition of a grammar for the teaching of Spanish and French as foreign languages, or writing public appeals to Philip II advocating religious tolerance, ${ }^{15}$ the latter engaged in the development of the ideas that would eventually inform his ground-breaking volume on international law (De jure belli, Hanau, 1598). Gentili's proposals included a separation between civic and religious allegiance founded upon the disengagement of law from theology.

All of this shows that Mabbe's education and early career in Oxford acquainted him with Ramism and also exposed him to a rich and sophisticated background on the theological, political and legal disputes of the day, as it also related him to scholars interested in teaching not just classical and modern rhetoric, like Butler, but also modern languages. Among the latter was John Sanford, who took his BA from Magdalen College on 17 December 1586, and was also a chaplain there from 1593 to 1616. It was as chaplain too that he joined Mabbe in Sir John Digby's diplomatic mission to Madrid in 1611. This year saw the publication of Sanford's Propylaion, or An entrance to the Spanish tongue (London: Th. Haveland and N. Butter, STC (2nd ed.), 21738), a 62pagebooklet with a very practical purpose: Sanford distributed copies among the members of the embassy that was about to depart for Madrid. Sanford enjoyed a certain reputation as a neo-Latin

\footnotetext{
12 The quotation is taken from the text of the 1621 edition of Butler's Rhetoricae Libri Duo (London: William Stanby, STC (2nd ed.), 4199.5), [A3 $]$.

13 See Andrew W. Taylor 'Humanist Philology and Reformation Controversy: John Christopherson's Latin Translations of Philo Judaeus and Eusebius of Caesarea', in Tudor Translation, ed. F. Schurink (London: Palgrave, 2011), 79-100, pp. 857, et passim for further details on Humphrey's connections.

${ }_{14}$ Thus, The Nobles, or of Nobilitye (London: Thomas Marshe, 1563, STC (2nd ed.), 13964)

${ }^{15}$ Reglas gramaticales para aprender la lengua española y francesa, (Oxford: Joseph Barnes, STC (2nd ed.), 5789); Lettre envoyée à la majesté du roy des Espaignes, first published in 1567 in Antwerp by Gilles Coppens van Diest.
} 
poet, translated unmistakably Catholic works, and also produced other practical dictionaries, grammars, and phrase-books, in French, Latin and Italian. ${ }^{16}$ Four years after his departure for Madrid as part of Digby's embassy, we find him back in England, employed in Lambeth Palace as a domestic chaplain for the Archbishop of Canterbury, George Abbot—about whom more below. Sanford also corresponded with the English ambassador in Paris, Sir Thomas Edmondes, with whom he exchanged information on the progress of Digby's mission in Madrid. I shall conclude this survey of Oxford scholars and Magdalen fellows with Ambassador Digby himself (1580-1653), who was to become $1^{\text {st }}$ Earl of Bristol. He had been admitted to Magdalen in 1595 and created an MA on 30 August 1605. After the Gunpowder Plot he had gradually become a diplomatic and political agent of the first order. He also appears closely associated with Sir John Strangways, who was like Digby another prominent member of the Dorset aristocracy, and the dedicatee of several of Mabbe's translations. I shall return to Strangways and the Dorset connection in the last section of my essay. Before that, the second part of this article will look at some primary evidence that provides important information about Mabbe's international and domestic engagements, starting with his first documented contact with Spain as Digby's secretary.

$\cos$

While in Madrid, Mabbe must have become familiar with its thriving literary scene, its public theatres - the so-called corrales de comedias — and its literary controversies — such as that stirred by Lope de Vega's Arte Nuevo de Hacer Comedias, an oration the Spanish playwright pronounced in the Academia de Madrid around 1607-1608. We know very little, however, about Mabbe's activities in the Spanish capital, except for the well-known fact that he sent to Oxford, through the mediation of Leonard Digges, a copy of the 1613 edition of Lope's Rimas for Will Baker. ${ }^{17}$ Sixteen years younger than Mabbe, Leonard Digges (1588-1635) was another well-travelled, internationally educated scholar, and like Mabbe a translator who rendered Gonzalo de Céspedes y Meneses' Poema trágico del español Gerardo, y desengaño del amor lascivo into English as Gerardo the Vnfortunate Spaniard, Or a Patterne for lascinious louers (STC (2nd ed.), 4919) published by Edward Blount in 1622-the year he also published The Rogue. Like Mabbe, Digges contributed some of the opening poems in Blount's edition of Shakespeare's First Folio of 1623.

Unfortunately, the only manuscript testimony we have by Mabbe from Madrid is a letter dated around the second half of 1612 that does not convey any of his impressions on the literary scene. But it does provide hints about Mabbe's connections back at the English court that will throw some light on part of his production, as it also portrays our man as a diligent informer for his English correspondents. ${ }^{18}$ Mabbe's letter mentions the death of an important person at the English court—in all likelihood Robert Cecil, Earl of Salisbury, who died on May 24th 1612. Mabbe declares in the letter that although he also received this news from his correspondent in a letter of May $28^{\text {th }}$, this momentous event had already reached his ears through other unspecified channels: ' $\mathrm{S}$. I have receiued yours of the 28 of May, but before / thei came unto my handes, the unhappy tidings came hither of / Y Y. Lordesdeathe' (ibid. fol. $210_{\mathrm{r}}$ ). ${ }^{19}$ Mabbe also adds that the Spaniards 'seeme to bee well pleased' at the death of this important minister. ${ }^{20} \mathrm{He}$ also announces the appointment of a new ambassador in London, Don Diego Sarmiento de Acuña, i.e. Gondomar, who-Mabbe reassures his addressee-'will agree well with the English disposition'. Peppered with Italian and Spanish expressions and phrases, matter-of-fact, and devoid of spectacular or breaking news, the letter constitutes nevertheless a good example of the type of exchange of information that took place within the international networks of diplomats and intelligencers.

The identity of Mabbe's addressee cannot be indisputably established, but using circumstantial evidence, the most likely candidate appears to be George Calvert, first Baron Baltimore. Educated as a Catholic, Calvert studied foreign languages in Oxford, where he of

\footnotetext{
${ }^{16}$ See Stoye, 1989, p. 254, and 'John Sanford', DNB, by Charlotte Fell-Smith, rev. Elizabeth Haresnape.

17 See Guadalupe Martínez Lacalle, ed. and introd. James Mabbe, trans. [Fernando de Rojas's] Celestine or the TragickComedie of Calisto and Melibea [the Alnwick manuscript] (London: Tamesis Books, 1972.), p. 9.

${ }^{18}$ National Archives, State Papers, Foreign, Spain, SP 94/19, fols. 210-211.

${ }_{19}$ May $28^{\text {th }}$ should therefore be the terminus post quem for a more precise dating of the letter.

${ }^{20}$ Pauline Croft confirms in her article on Robert Cecil for the DNB that 'there was rejoicing in Madrid at his death' $(D N B)$
} 
necessity had to conform to the State religion. He matriculated in Trinity College during the Lent term of 1593-94, and after Oxford spent two years (1601 - April 1603) travelling on the Continent. ${ }^{21}$ Upon his return to England he became one of Cecil's secretaries-his knowledge of foreign languages must have been fundamental for this appointment. Always under the patronage of Cecil, he was appointed clerk of the Privy Council in 1610, and dispatched by Salisbury on an extensive trip to Europe to gather intelligence from the different English embassies abroad. After Salisbury's death in 1612, Calvert was put in charge of Spanish and Italian correspondence. According to J.D. Krugler, 'Salisbury's death left Calvert without a patron'22, and Mabbe in his letter refers to the great loss that Salisbury's death had been for his correspondent, since the later had grown under the shadow of the deceased's protection: 'But why doe I weaken his worthe by my imperfect prayses, / when I should rather firste condole $w^{\text {th }}$ you, \& then comforte you? / As therfore I am very sorie bothe for $t_{h}$. Generall \& your par- / ticular losse, whereof I am very sencible.' His mission abroad to gather intelligence from English legations might have also acquainted Calvert with Mabbe in Madrid - if they had not met years before in Oxford. The fact that later in his life (1624) Calvert openly announced his conversion to Catholicism must have also endeared him to Mabbe. At court Calvert was perceived, even before this public conversion, as belonging to the Spanish party-as opposed to the Protestant, Calvinist, anti-Spanish faction, led by, inter alia, Archbishop Abbot. Late in 1612 Lewis Bayly, one of the ardently Protestant chaplains of the recently deceased Prince of Wales, was reprimanded for publicly denouncing the presence of crypto-Catholics among the king's councillors:

One Bayly, a chaplain belonging to the prince, preached on Sunday last, at St. Martin's, near Charing Cross, that the prince told him, not a month before he died, that Religion lay a bleeding; 'and no marvel,' said he, 'when divers councillors hear mass in the morning, and then go to a court sermon, and so to the council, and then tell their wives what passes, and they carry it to their Jesuits and confessors,' with other like stuff; for which he was called before my Lord of Canterbury the next day, and, I hear, silenced. ${ }^{23}$

Bayly may have been indirectly referring to Calvert, who was at the time still a member of the Privy Council. Since his patron, Salisbury, had died on May 24th 1612, a few months before the date of Bayly's finger-pointing sermon-pronounced early in November of that year-Calvert's opponents might have thought that he had as a result become a more vulnerable target. In his letter Mabbe also adds that-whereas Cecil was the link that processed the information which passed between Mabbe and Calvert: 'the copula... of our correspondencie'- his loss would not necessarily preclude Mabbe from continuing to pass information on to him. He then adds that he awaits instructions on how to safely convey this intelligence:

As therfore I am very sorie bothe for $\mathrm{t}_{\mathrm{h}}$. Generall \& your par- / ticular losse, whereof I am very sencible.... Thus muche the honour $w^{\text {ch }}$ hee deser- / ued of all good Patriotts, $\& t_{h}$ love I beare unto your / selfe, hathe forced mee to speake of him; \& more I will / not, leastet ${ }_{h}$. more I remember him, the more I should / rebiue your greife. And though hee bee dead, who was / th. copula as it were of our correspondencie, considering / your place of imployment under him, yet will I live still the same / man in the continuance of my writing unto you, / or in th. exercise of all other freindly offices wherein you / shall haue occasion to use mee. Intreating that in $\mathrm{y}^{\mathrm{r}} /$ next you will giue mee direction for convayance, that / thei may come safe unto $\mathrm{y}^{\mathrm{r}}$ handes. (Fol. 210 $\mathrm{r}_{\mathrm{r}-\mathrm{v}}$ )

\footnotetext{
${ }^{21}$ J.D. Krugler, English and Catholic: The Lords Baltimore in the Seventeenth Century (Baltimore: Johns Hopkins University Press, 2004), p. 30.

22 Krugler, 2004, p. 37.

23 John Chamberlain to Sir Dudley Carleton, London, Nov. 19, 1612. (Thomas Birch, ed. The Court and Times of James the First: Containing a Series of Historical and Confidential Letters, In Which Will Be Found a Detail of Public Transactions and Events in Great Britain during That Period, With a Variety of Particulars Not Mentioned by Our Historians, 2 vols. (London, 1849)1. 206-208, p. 208). The same incident was also reported a few days later in a letter from Richard Earl of Dorset to Sir Thomas Edmondes, from Dorset House, November 23, 1612. (Birch,ibid.1.210-11). See also Krugler, 2004, p. 43; Albert J. Loomie, 'A Jacobean Crypto-Catholic: Lord Wotton', The Catholic Historical Review, 53(1967), 328-345, 328.
} 
After his stay in Madrid it appears that Mabbe was granted another leave of absence late in 1620 from his position in Magdalene College. Mabbe's patron, Sir John Digby was sent to Spain again to pursue the marriage treaty in April 1617, and then again in 1621.24 Martínez Lacalle and Russell have speculated with the possibility that this leave of absence was granted so that Mabbe could once more travel to Spain, and become part of the English embassy in Madrid at around the time Prince Charles and the Duke of Buckingham went there on their famous mission to negotiate a wedding between the Prince of Wales and the Spanish Infanta María. ${ }^{25} \mathrm{As}$ we shall see, there is proof that in 1622, and for most of 1623, the year of Charles and Buckingham's voyage to the Spanish court, Mabbe was back in Oxford. The Magdalen College Register records another series of leaves granted to Mabbe after 1620, to wit "six months... 1 Aug., 1621; three months, 16 Feb., 1623; a year, 24 Dec., 1623; 24 Dec., 1624, 24 Dec. 1625". ${ }^{26}$ Although it is tempting to speculate that Mabbe coincided in Madrid with Charles and Buckingham, we lack any evidence that can prove or even suggest it other than these records. And indeed it could well be the case that these leaves of absence were granted for a return to Spain, but Mabbe might have also travelled somewhere else, for instance, the Spanish Netherlands where, as we shall see, he had just established new contacts.

Gary Taylor has revealed the existence of a letter sent by Mabbe to William Trumbull, an English diplomatic agent in Brussels, from Oxford on 23 October 1622. Here Mabbe declares that he had spent six years employed abroad: 'I cannot tell whether I should impute yt my discretion (though it please you to stile yt so) or my destinie, that after a six years imployment abroade, I should retyre my selfe to my Cell'. ${ }^{27}$ This reference to his six years spent abroad match with the data provided by the Magdalen Register, which records a continuous series of leaves granted to Mabbe between December of 1610 and 1616, after which there is a gap until 1620, when Mabbe again obtained another six-month leave. Whether those six years (i.e. 1610-1616) were exclusively spent in Spain, or whether he also travelled somewhere else is another matter. Again, Gary Taylor has provided primary evidence that can point to Mabbe's activities abroad, and also to what he was doing back in England between ca. 1616 and 1622. This evidence appears in a letter from William Abbot, Archbishop of Canterbury, to Trumbull on July $5^{\text {th }} 1622$ in which he reports that Mabbe 'lived long in Italy and Spaine'. Mabbe could, therefore, have spent at least a portion of these six years in Italy. But Abbot's letter tells us much more about Mabbe's activities, if not abroad, at least while he was back in London:

Of Mebbe I must say this to your selfe, and afterward other things for him. Hee lived long in Italy and Spaine, and as time showes, brought home many vices with him. Pretending a desire to bee reformed in religion (which bothe in him and others hath often catched mee, and cost mee great summes of mony) I intertained him, and approving his good parts, after one yeere I tooke him into my chamber. His plenty made him wanton, idle, and machinating mischeefe, and afterward I founde that hee served Diegos and the Jesuites turns vpon me. I had advertisement out of Italy that I had a perpetual spy vpon mee who gave intelligence of the most minute matters concerning mee, and all to evill. Vpon the best advice that I could take, it fell properly vpon Mebbe, and to make triall of it, I called him privately vnto mee, and after a fewe wordes, I put my hande into his pocket to see what papers hee had there. I founde diverse strange attempts of his machinations vnder his

\footnotetext{
${ }^{24}$ See Paul A. Welsby, George Abbot. The Unwanted Archbishop: 1562-1633(London: S.P.C.K., 1962), p. 84.

${ }^{25}$ Martínez Lacalle, p. 10-11; see also P.E. Russell, 'A Stuart Hispanist: James Mabbe", Bulletin of Hispanic Studies, 30(1953), 75-84, p. 80. Another Magdalen fellow, Accepted Frewen—who would become President of the College in 1626, did accompany Digby as chaplain in his 1617 embassy to Spain, and he was in Madrid with Digby too when Charles and Buckingham showed up to negotiate the Spanish Match (W.J. Sheils, 'Accepted Frewen', DNB)

26 'From 1610 onwards, until his resigned his fellowship in 1633, he appears from the perpetually renewed leaves of absence to have lived chiefly abroad, especially in Spain with the Earl of Bristol. On 31 Dec., 1610, and the following 29 Jan., he had a year's leave, with permission to retain all emoluments while in Spain, and 4s. per week for commons; another year, being still in Spain, 29 Jan., 1611/2; again, 13 Jan., 1613/4; again, still 'in exteris', 21 Dec., 1615, with 4s weekly, continued in 1616, and afterwards; six months' leave, 29 Dec., 1620, and 1 Aug., 1621; three months, 16 Feb., 1623; a year, 24 Dec., 1623; 24 Dec., 1624, 24 Dec. 1625; three months, 27 Jan, 1629/30; a year, 24 Dec. 1630; and, finally, three months, 24 Dec., 1631.' (W.D. Macray, A Register of the Members of St. Mary Magdalen College, Oxford. New Series. Vol. III (London: Oxford University Press, 1901) pp. 122-123.)

${ }_{27}$ Gary Taylor 'The cultural politics of Maybe'. In Lancastrian Shakespeare: Theatre and Religion, eds. R. Dutton, A.G. Findlay \& R. Wilson (Manchester, UK: Manchester University Press, 2003), pp. 242-258, p. 243.
} 
owne hande, such as could not bee but in a scholar of the Jesuites, and one that had bene in Italy. Above the rest I founde one paper in Spanishe, \& some part of it in cipher, the rest in Turke wordes wherein were related diverse things whiche hee heard from the LL. whispering one to another at Starre chamber, the like at the Court, in my chamber, at my table, all to make discord between great persons, \& muche of it fained. ${ }^{28}$

Unfortunately, Abbot does not specify the dates. But we must note that ca. 1614-15, Mabbe's colleague in Madrid, John Sanford-who had been Digby's chaplain in his 1611 Spanish embassy, and was chaplain in Magdalen College too until 1616-was also working for Abbot as his domestic chaplain in Lambeth. ${ }^{29}$ As one of the leaders of the anti-Catholic, anti-Habsburg faction at court, Abbot vigorously opposed the Spanish Match. If, as Abbot's letter to William Trumbull proves, Mabbe spied on Abbot for the Catholic, pro-Spanish faction, and / or for a foreign patron, Mabbe must have been employed at Lambeth or at Abbot's household at some point ca. 1617-1622.

The domestic political background to these years-i.e. ca. 1614, when Sanford was working for Abbot, and 1622, when we have evidence of Mabbe in Oxford and Abbot informs Trumbull about Mabbe's recent activities as a spy-is dominated by the poisoned relations of James I with Parliament, and his attempt to negotiate a treaty with Spain through a marriage that could bring in a large dowry to fill James' empty coffers, and thus liberate him from a compromise with more recalcitrant Protestant MPs. In exchange for this marriage, Spain demanded a repeal of the antiCatholic legislation, which Abbot and the other Protestants firmly opposed. During this period Abbot was busy trying to expose crypto-Catholics, and to this effect he exchanged a considerable amount of information with Trumbull, who had an extensive network of informants in the Spanish Netherlands, and elsewhere in Europe. Things became even more complex in 1618 with the crisis of the Palatinate, and the onset of the Thirty Years' War, which exacerbated the differences between the pro-Spanish and the Protestant factions..$^{30}$

Abbot's letter to Trumbull of 5 July 1622 is part of the flurry of correspondence that Abbot and Trumbull exchanged. And one of the most interesting pieces of information that this letter contains is a reference to the fact that, even after being exposed as a spy, Mabbe persisted and sent the monarch defamatory papers about Abbot. Those documents were examined by secretaries Naunton and Calvert, after which Mabbe was thrown in prison. After this period in jail-three quarters of a year, the letter says-Abbot reports that a chastised Mabbe decided to inform about other agents working for the pro-Spanish faction. The letter also appears to suggest that Mabbe had spent some time with Trumbull in the Spanish Netherlands ('In the meane time, being there with you, he hath discovered another mans villany against mee'), passing information on to Abbot. This stay in Brussels, working with or for Trumbull, could be the reason for Mabbe's leaves of absence in 1620 and / or 1621:

I questioned him about it, \& promised him pardon if hee would deale truly with mee, who set him on worke. Hee refused it, \& I turned him out of my doores. This came so vnexpected on him, that hee knew not whiche way to turne him, but after a moneth taking ill counsel, hee gave the kinge two or 3. sheetes of paper agains mee, wherein some fewe wordes were lewde inoughe. The kinge acquainted mee with it, and I prayed that his my. would commend the examination of all things, to $\mathrm{mr}$ Secretary Nunnton, and $\mathrm{mr}$ Secretary Calvert. They heard it, \& reporting all to the king and among the rest of his plot to bee a Spy vpon his my, in a service of my L. of Buckingham whiche hee then aimed at, by his mys. direction hee was laide vp close prisoner in the Gate-house, \& there continued $3 \mathrm{q} \sim \mathrm{rs}$ of a yeare till hee had made a good submission vnto mee whiche I accepted yet chained him with bondes that hee should bee forth-coming, whiche now hee hath broken. In the

\footnotetext{
28 Quoted by Taylor 2003, pp. 245-46.

${ }^{29}$ Charlotte Fell-Smith, 'John Sanford', DNB, rev. by E. Haresnape.

30 Welsby, 1962, p. 80. For the domestic and international political background see Roy E. Schreiber, The First Carlisle. Sir James Hay, First Earl of Carlisle as Courtier, Diplomat and Entrepreneur, 1580-1636 (Philadelphia: Transactions of the American Philosophical Society, vol. 74, part 7, 1984) pp. 39-40; Robert Zaller, The Parliament of 1621. A Study in Constitutional Conflict (Berkeley, Los Angeles, \& London: University of California Press, 1971), pp. 130-133. On the crisis in Bohemia and the impact on the pro-Spanish party, see Welsby, 1962, pp. 87-8.
} 
meane time being there with you, he hath discovered another mans villany against mee who probably is as false a varlet as hee himselfe was. ${ }^{31}$

Consequently if Mabbe left for Spain early in 1611, and in 1622 he declared that he had spent 6 years abroad - as the Magdalen records appear to confirm—and if Abbot informs Trumbull that Mabbe spied on him, was exposed and subsequently jailed for it through the intervention of secretaries Naunton and Calvert-who were appointed as secretaries, respectively, in 1618 and 1619-then Mabbe cannot have gone to jail before 1619 or after July $5^{\text {th }} 1622$ - the date of the letter in which Abbot tells Trumbull about Mabbe's imprisonment.

Another hint that Mabbe might be informing-or at least pretending to inform-the Protestant party stems from a letter of 30 May 1623, from Mabbe's publisher, Edward Blount to Trumbull..$^{32}$ Blount starts his letter with the following declaration: 'A strickt charge was layed vpon me by my good friend mr. Mabb to send this inclosed safe to you: I am bound to obserue his Comand, and serue you'. What was Blount sending to Trumbull from Mabbe? A book, perhaps? Maybe a fresh copy of the recently published The Rogue? And if so, why must whatever it is be sent 'inclosed safe', as a 'strickt charge'? Towards the end of May 1623, thus, Mabbe was back in Oxford, after the three-month leave he had just obtained on 16 February of that year, and he had something for Trumbull. This letter also proves, incidentally, that Blount the publisher was sending Trumbull the latest editorial novelties, and that, just a few months after the publication of The Rogue, which appeared in 1622 as Mabbe's literary debut, and just a few months away from the publication of Shakespeare's First Folio in 1623, Edward Blount, James Mabbe and William Trumbull were in frequent correspondence with each other, as each of them also went about their own particular business in their respective fields: translation, publishing, diplomacy, and the exchange of public and secret intelligence.

But whence Trumbull's interest in Mabbe? 'When your sonne goeth to Oxon ', says Abbot on 5 July 1622, 'I shall recommend him in the best fashion that I can.' ${ }^{33}$ Trumbull's son is about to go to Oxford and it appears that he has requested some letters of introduction. But Trumbull would also like to hear what Abbot may have to tell him about Mabbe, since he will be tutor to his son in Oxford, where our man will teach him Spanish. This is what Mabbe himself tells Trumbull in his letter from Oxford on 23 October 1622:

I am glad that my residing in Mag. Colege hathe brought the sonne of so deseruing a father to my knowledge that I may expresse my love to you in him.... Wee are now entred upon the Spanishe. And for I am acquainted with the Spanishe fleagme, and how things goe on there muy de espacio, ${ }^{34}$ I hope he shall winne ouer the Spannishe, before the Spanishe Lady come over.

Another letter from Blount to Trumbull, dated just two weeks later (8 November 1622), confirms Mabbe's status as the tutor of Trumbull's son:

I must needes come in $\mathrm{w}^{\text {th }}$ a Postscript too, and tell $\mathrm{y}^{\mathrm{t}}$ your sonne is well, and a great proficient in the spanishe tongue, by the meanes of $\mathrm{m}^{\mathrm{r}}$. James Mabbe, of Magdalen College who takes as muche delight in reading to him and other gentlemen of that howse; as they take in that their desyre. ${ }^{35}$

Mabbe will groom Trumbull's son in the Spanish language 'before the Spanishe Lady come over', i.e. before the new wife of prince Charles arrives in England-provided the difficult negotiations taking place in Madrid can finally succeed. The rest of the letter precisely contains Mabbe's political analysis regarding the efforts of Digby and his team in Madrid, the difficult international situation, and the troubles that beset the complex negotiations for the Spanish Match. A cautious Trumbull

\footnotetext{
31 Abbot to Trumbull, quoted by Taylor, 2003, p. 246. For further details, see Taylor, 2003, pp. 247-248.

${ }^{32}$ Fol. 116 [before numbered as 46] in BL, Trumbull Miscellaneous Correspondence, Add. MS 72365.

33 Abbot to Trumbull, quoted by Taylor 2003, pp. 245-46.

${ }^{34}$ Muy de espacio, sic, in Spanish in the original, i.e. very slowly.

35 Edward Blount's Letters to Trumbull - BL, Trumbull Miscellaneous Correspondence, Add. MS 72365. Taylor, 2003, pp. 248-49.
} 
appears to be hedging his bets, exchanging information with the anti-Habsburg Abbot and simultaneously grooming his son in Spanish in preparation for the arrival of the 'Spanishe Lady'.

As Secretary of State, Naunton was responsible for the coordination of the counterespionage against foreign embassies in London, so it is only natural that after Abbot's report, the affair of Mabbe's intelligence activities fell into his hands. Whereas domestic counter-espionage was the responsibility of Naunton, the trade of secret information from abroad was generally in the hands of ambassadors. For instance, Digby's intelligence network was responsible for intercepting and decoding Gondomar's missives, whereas Sir Henry Wotton, the English ambassador in Venice, provided information about Italian Jesuit plots. According to Garret Mattingly, Gondomar was informed of the breaches in his secret correspondence with Madrid by Calvert, Naunton's fellow Secretary of State. ${ }^{36}$ If, as speculated, Mabbe was in Italy at some point between 1611-1616, and he afterwards informed for the Jesuits or the Spaniards - or for both — while working under Abbot, his activities as a Catholic spy may have been exposed by Wotton's counterespionage networks.

There are certainly many dark areas within Mabbe's activities these years that will remain obscure unless new evidence is unearthed. But in spite of the patchy evidence, the overall picture that emerges is quite revealing, and the fact remains that Mabbe traded in information, as he traded in literary, political, and religious capital between England and Spain. In turn, his publisher Edward Blount corresponded with William Trumbull and with other English diplomats abroad, with whom he dealt in books, manuscripts, art objects, and other sorts of luxury goods. And in his own turn Trumbull corresponded with a large network which comprehended political and religious contacts (Abbot), art and book dealers (Blount), as well as artists (notably, Rubens), besides a large variety of secret informants, or international scholars and linguists like Mabbe. ${ }^{37}$ Trumbull's papers in particular are still a much underexplored trove of information on these international networks, their artistic and literary relevance, and other manifold dimensions besides their obvious importance for diplomatic, political and religious history.

There are therefore several dimensions to Mabbe's activities and connections besides his production as a literary translator. In academia this included rhetoric and instruction in foreign languages. His literary activities relate him to Blount, Jonson, or Florio. Blount and Abbot link him to Trumbull, who then branches back into the other categories, since Trumbull's many correspondents included Shelton - the Irish Catholic translator of Cervantes' Don Quijote - and Thomas Lodge-translator of Seneca, Luis de Granada, and Josephus. ${ }^{38}$ In diplomacy, Mabbe's activities as Digby's secretary in Madrid links him with those in the Dorset gentry who were his patrons and dedicatees, in particular Sir John Strangways. The last part of my article will deal with these patrons, and what they may tell us about Mabbe's translations.

In 1622 Mabbe dedicated The Rogue to Sir John Strangways, who had also been the dedicatee of the first version of Mabbe's translation of La Celestina, the so-called Alnwick Manuscript (ca. 1602-1603). ${ }^{39}$ Strangways matriculated from Queen's College, Oxford, in 1601, and on 4 January 1611 he was admitted to the Middle Temple, by which time he was already a knight. Under Digby's patronage, he came to represent Dorset in the Parliaments of 1614, 1621, and 1624, whereas in 1625 and 1626 he stood as MP for Weymouth and Melcombe Regis. More than twenty years after the Alnwick manuscript, and seven years after the first edition of The Rogue, Mabbe dedicated another translation collectively to Sir John Strangways, Sir Lewis Dyve and their respective wives: it was his Devout Contemplations, Cristóbal de Fonseca's internationally popular

${ }^{36}$ Garrett Mattingly,Renaissance Diplomacy (Baltimore: Penguin, 1955), p. 225. For further details on Naunton's anti-Catholic counter-espionage, see Schreiber, 1981, pp. 45-47.

37 On Rubens's career as a diplomat and secret informant, see Emile Cammaerts, Rubens, Painter and Diplomat (London: Faber \& Faber, 1932), also Jozef Muls, Rubens, the Diplomat, 1963. For Trumbull, see his entry in the DNB. (Sonia P. Anderson). On Blount's many trades see also his DNB entry.

${ }^{38}$ For an account of Trumbull's correspondence with Thomas Shelton, the translator of Don Quixote, see J. George, 'Thomas Shelton, Translator, in 1612-14”, Bulletin of Hispanic Studies, 25 (1958), 157-164. See also Nigel Smith, 'Windmills over Oxford: Quixotic and other subversive Spanish narratives in England, 1606-1654' Journal of Medieval and Early Modern Studies 39 (2009), 95-117.

${ }^{39}$ For the dates of the Alnwick Manuscript, see my introduction to the MHRA edition of The Spanish Bawd (forthcoming in 2013) 
collection of sermons mentioned above. Sir Lewis Dyve was Digby's stepson. He had married John Strangways's daughter, and had also spent some time in the Spanish embassy during Digby's tenure there. Like other members of the Dorset gentry he was suspected of crypto-Catholicism. ${ }^{40}$

His patrons also relate Mabbe with a via media in the confrontation between the monarchy and Parliament, a position which some historians have described as constitutional royalism. This defence of the rule of law vs the absolutism of royal prerogative constituted the backbone of Sir John Strangways's political career, leading up to the Civil War. Like Digby, he supported Buckingham's impeachment in 1626, and on 5 June of this year he responded to Dudley Carleton's threat that the king might turn to 'new counsels' by asserting that: 'all kings that are not tyrants or perjured, will keep themselves within the bounds of the laws of the[ir] own kingdoms, and those that counsel them to other ways are vipers fitting to be cast out, and pests of the commonwealth.' ${ }^{41}$ During these years, Digby had also polemicized in Parliament with Buckingham over their respective roles during the negotiations for the Spanish Match back in Madrid.42

This background throws interesting light on Mabbe's translation of Juan de Santa María's República y Policia Cristiana (Madrid, 1615). Santa María's volume deals, inter alia, with the question of counsel and royal favourites, which at the time was a most relevant topic not just in Spain or in England, but all over Europe: this was, after all, the age of Buckingham, Olivares and Richelieu. Juan de Santa María's treatise was enormously influential in Spain towards the end of the reign of Philip III and the onset of Philip IV's. ${ }^{43}$ As mentioned above, Mabbe's translation is also frequently quoted by the late historian Kevin Sharpe as a relevant text for a proper understanding of early seventeenth-century theory of counsel in England. ${ }^{44}$ Ideas such as the notion that the monarch is only part of a cosmic order that grants him absolute power, but which also demands the exercise of this power alongside the principles of Nature and Reason feature in Santa María's volume, and they also run parallel with the sort of political positions defended by Strangways.

Mabbe's translation of Juan de Santa María's work on counsel must also be contemplated against the political background within which the Spanish version originated, and in parallel with the situation in England. For this is a case of political and cultural translation by means of which Mabbe transposed Santa María's highly influential treatise on to the English milieu, where the political debate oscillated between the absolutist tendencies of Charles I, the radical Parliamentarism of the Puritans, and the via media of the constitutional royalists. Upon his arrival in Madrid early in 1611, Mabbe had found the Spanish court engaged in political strife concerning the influential Duke of Lerma, king Phillip III's favourite. Thus, only a year before Digby's embassy, a pamphlet had been published against Lerma, in the form of an appeal to the monarch himself (Pérez de Herrera's Al católico y poderosíssimo rey de las Españas y Nuevo Mundo... Felipe III, Madrid, 1610). The author of República y policía cristiana, Fray Juan de Santa María was also a prominent

\footnotetext{
${ }^{40}$ For more details on Mabbe's connection with the Dorset gentry, see Martínez Lacalle, 1972, pp. 11-12.

41 W. B. Bidwell and M. Jansson, eds. Proceedings in Parliament, 1626 (New Haven \& London: Yale University Press, 4 vols., 1991-1996), 3.370. Strangways proclaimed on May 1st, 1628 that 'what has been acted to the prejudice of the liberties of the subject of late, had it been in former ages, had been sufficient to have shaken the frame and foundation of the kingdom' (Bidwell and Jansson, eds. 3.197). See also M.F. Keeler, The Long Parliament, 1640-41: A Biographical Study of Its Members (Philadelphia: The American Philosophical Society, 1954), 353-54; also Thomas G. Olsen, ed, The Commonplace Book of Sir John Strangways (1645-1666) (Tempe, AZ: Arizona Center for Medieval and Renaissance Studies \& Renaissance English Text Society, 2004), pp. 2-9, who claims that 'Strangways worked vigorously for the impeachment of Buckingham in 1626, eventually becoming one of Buckingham's great enemies in Parliament.' For more details on Strangways as one of the constitutional royalists, see David L. Smith, Constitutional Royalism and the Search for Settlement, c. 1640-1649. [1994] (Cambridge University Press, 2002), pp. 57-61, who describes this group's shared assumptions as 'a commitment to the rule of law, and an avoidance of the more extreme forms of godly zeal' (ibid., p. 61)

${ }^{42}$ With Digby in Madrid during the negotiations for the Spanish Match was another Englishman, James Howell. Howell was a well-travelled linguist, closely associated with Ambassador Digby, and with Sir Kenelm Digby. He was also one of the 'tribe' of Ben Jonson, with whom he shared the kind of neo-stoicism inspired by Justus Lipsius, Howell authored, inter alia, a volume titled Instructions for Forreine Travel (1642), with practical information on Spain, France and Italy. He became a tolerant and moderate royalist, who defended the traditional role of Parliament, as he rejected the radicalism of the Puritans. Besides his own intellectual production, Howell also edited the works of John Selden and Sir Robert Cotton. He was an interpreter, a translator, and in 1660 produced a dictionary in four languages (Lexicon tetraglotton). In his entry on him in the DNB, D.R. Woolf describes Howell as 'a moderate, appealing to common sense, compromise, and charity rather than to rigid principles and partisanship'

43 John H. Elliott, The Count-Duke of Olivares. The Statesman in an Age of Decline (New Haven \& London: Yale University Press, 1986), pp. 90, 102.

${ }^{44}$ Sharpe, 2000, pp. 55-57.
} 
member of the anti-Lerma faction, one of whose most relevant leaders was a member of the royal family itself, the ultra-Catholic Infanta Sister Margarita de la Cruz. For Santa María in Castile-who deplored the fact that Philip III left important affairs of state in the hands of his corrupt favourite, the Duke of Lerma — and for Mabbe and his patrons in England—who thought that the monarch should keep within the bounds of law, and abandon counsel that advised otherwise- the solution was a consultative monarchy. And if for Santa María in Spain the problem had been the evil influence of the corrupt Duke of Lerma, for Mabbe and his patrons the imminent dangers for the commonwealth stemmed from the corruption and evil counsel of Buckingham first, and then by the absolutist tendencies of Charles I's personal rule compounded on the other side of the religious and political divide by the unsettling radicalism of the Puritans..$^{45}$

But let's return to the original text of Mabbe's Devout Contemplations (1629), i.e. Cristóbal de Fonseca's Discurso para Todos los Evangelios de la Cuaresma, which was first published in Madrid in 1614. It was dedicated by Fonseca to Cristóbal de Sandoval, Duke of Uceda, who happened to be the son of Francisco de Sandoval y Rojas, i.e. the Duke of Lerma. Within the intricate networks of factional infighting at the Hispanic Habsburg court in the 1610s, Uceda became his father's main opponent in the competition for the favour of King Philip III. Fonseca's dedicatory epistle to Uceda makes explicit references to the political enmity between father and son as he also publicly reassures his dedicatee by admitting that there are occasions when sons are under an obligation to contradict or oppose their fathers. Fonseca and Santa María's volumes were published in 1614 and 1615, coinciding with Mabbe's presence in Madrid, and at a time when political debate and intrigue gravitated around matters relating to the crown's foreign policy, the political infighting between the entourages of Philip III and his heir, and the position that the different players were adopting in preparation for the transfer of power when the moment arrived. This latter issue involved the allimportant question of counsel and royal favourites. ${ }^{46}$ Mabbe's interest in authors whose works had emerged from this situation back in Castile in the 1610s, and their transplantation to England in the 1620 s and the early 1630s - when the transfer of power between James I and Charles I was unfolding under the political influence of Buckingham in the midst of a complex international situation, and later on, when the English monarch was trying to rule without Parliament-is quite revealing. Mabbe was trading in more than literary capital, or secret intelligence. With his translations he was providing a blueprint, and also appropriating useful political ammunition, for his patrons.

There is yet another translation by Mabbe during these years that reveals the sort of exchanges that engaged his endeavours. Dated in Madgalen College on 27 December, 1626, Mabbe's manuscript Observations touching some of the more solemne tymes and festival days of the yeare (BL Harleian MS. 5077) belongs in these years of political, religious, and dynastic transitions in England. This document is dated only four years after the Archbishop of Canterbury had told William Trumbull in his letter of 5 July 1622 that he had had Mabbe imprisoned as a spy, because, 'hee served Diegos and the Jesuites turns vpon me'. ${ }^{47}$ Mabbe's Observations is the only remaining copy of a manuscript that has never been published. None of those who have approached Mabbe's production have paid much attention to its actual contents, other than taking at face value what Mabbe himself says in the dedication to John Browne, i.e. that it is a translation from an original that so far remains unknown. Mabbe concludes his dedicatory epistle to Browne thus:

As in Pictures the Counterfayt seldom answeares in every particular to the true life of the Originall; so is yt in Translations out of one Language into another. yet I dare promise you that this hand of myne hathe beene so carefull in the limning of this little peece; that there is bery litle odds betwixt the Originall \& yt. ${ }^{48}$

\footnotetext{
${ }^{45}$ Elliott, 1986, p. 95. For the international background, which relates domestic controversies in England and in Castile to the Thirty Years' War, see also G. Parker, Europe in Crisis: 1598 - 1548. ([Fontana Press, 1979]. 2nd ed. London: Blackwell, 2001), pp. 112-119; Richard Cust, 'News and politics in early 17th-century England', Past and Present, 112(1986), 60-90, pp. 78-79.

${ }^{46}$ For more details on the enmity between the two Sandovals see Antonio Feros, El Duque de Lerma: realeza y privanza en la España de Felipe III (Madrid: Marcial Pons, 2002), pp. 414-15.

47 Abbot's letter to Trumbull, quoted in Taylor, 2003, pp. 245-46.

48 BL Harleian MS. 5077, fol. $2^{*-v}$. On John Browne as the dedicatee of this manuscrirpt, see Yamamoto-Wilson, 2012, p. 331.
} 
The margins are heavily annotated with references to Scripture, and other authorities, that support the doctrines contained within the main body of the text. The first page of the manuscript sets off with a lengthy series of disquisitions on the origins of the Sabbath and its evolution-these were also the years of the sabbattarian controversies in England. ${ }^{49}$ There are references to emperor Constantine and his decrees, or to the differences between the Sabbath in the Old Testament and the Sunday (i.e. the Dominicus, Day of the Lord) which took precedence after the Old Law was derogated by the New Testament. Page 85 of the manuscript includes a section titled 'Of $\mid$ The Institution of the blessed Sacrament', page 87 contains a heading that reads 'Of $\mid$ The Ceremonies of the Masse, and how \& by | Whome yt was augmented'. Page 59 features a section on indulgences, that reads 'The use of Indulgences is not newe, but hathe yts Originall from the Apostles', and proclaims that the Pope and the Holy Church are legitimized to grant this sort of 'Sacramentall Absolution'. The list could be much longer, but let me just finish with page 53, which contains the following 'Confession of Faythe':

For to professe my selfe, that I am a Catholick; And that as heere amongst Christians, I shall not forbeare to faste for any thing whatsoever that shall bee sayd or done unto mee; so likewise, shall I not cease to doe yt, were I amongst Hereticks, or Indifells. And I imbrace and receive this Ordination, as made by the Apostles, by the inspiration of the holy spirit.

This is a necessarily short account of a long, unpublished manuscript which without any doubt deserves more attention than it has received so far. For instance, the question of the original that it claims to translate has not been settled. But within the purposes of this article, it does illuminate this period of Mabbe's life. In 1622 Abbot told Trumbull about Mabbe's activities as a Catholic informant, for 'Diegos and Jesuites', sent him to prison, and then gave him another chance (although it appears, from the letter, that Mabbe recanted again). Indirectly proclaiming his innocence in his own letter to Trumbull a few months after Abbot's information became available to Trumbull, Mabbe nevertheless ambiguously declares that 'my retyrednes was out of election \& not constraint, I bolde yt no small bappines unto mee, that I am as I am' (my italics).

The situation for Catholics had significantly changed around 1626. Charles I had just married the Catholic Henrietta Maria in 1625-with a marriage contract that included secret concessions to Catholics - and he was crowned in February of 1626. It was only natural for Catholics to feel safer, even encouraged, under the new ruler. The Spanish Match may have failed, as did the pro-Spanish party, but their uncertainties had at least dissipated with the marriage of their new monarch with a Catholic princess. Calvert had just openly converted to Catholicism in 1624. And back home, in Oxford, the enthusiastic Laudianism of the new president of Magdalen, Accepted Frewen, must have also encouraged Catholics.Shortly after taking office as President of the college in 1626, Frewen-who, we must remember, had accompanied Digby to Spain in 1617 and 1621-immediately turned Magdalen into a quintessentially Laudian institution. He started redecorating the chapel and other premises, restoring what former President Laurence Humphrey in his Protestant zeal had removed back in the 1560s. In their history of Magdalen College, Cockayne, et al. (2008, p. 165) conclude that 'It seems likely that the President's [i.e. Frewen`s] innovations were at least partly informed by personal experience of Spain'. According to the Magdalen College records quoted above, Mabbe had obtained another one-year leave from his college, on 24 Dec. 1623. This leave would be subsequently extended on 24 Dec. 1624, and on the same date in 1625 , i.e. Mabbe was away for three consecutive years. Where he went, or what he did, we do not know. But he must have been busy preparing the manuscript whose dedicatory introduction he signed on December 27th 1626 , right at the end of this three-year leave, when he was back in Magdalen College, working under its recently appointed new President. ${ }^{50}$

49 On the Sabbatarian controversies, see chapter 5 in Christopher Hill's Society and Puritanism in Pre-Revolutionary England, (London: Secker and Warburg, 1964, pp. 145-218), also Leah Marcus's 'Introduction' to her The Politics of Mirth (London and Chicago: U. Press of Chicago, 1986, pp. 1-23).

50 After this one, Mabbe would not obtain another leave until late 1629 (three months); he would go away again for a whole year on 24 Dec. 1629; and his final recorded leave (three months) was obtained on Dec. 24th 1630 . Mabbe was continually on the go, right up until three years before he retired from Oxford, in 1633. 
The fact that in his dedication to John Browne Mabbe refers to a previous text of a similar nature (whose title he reports as Practicks of Meditations), of which this manuscript was an appendix, suggests that he had been providing his friends and patrons with manuscript texts of a decidedly Catholic nature-even as he was protesting his innocence with Trumbull, and proclaiming himself happy to be as he was:

$S^{r}$. This is but an Appendix, or litle peece of building annexed to that great worke wherew ${ }^{\text {th }}$. I presented you the laste yeare. The other was the Mansion House. This the Out-Offices, $\mathrm{w}^{\text {th }}$.out $\mathrm{w}^{\text {ch }}$ parts the forms could not conbeniently consiste. This Parte had beene finished $\mathrm{w}^{\text {th. }}$. the other, had not sicknes (an inebitable stopp) beene a hinderance to that busines. Now, to those Practicks of Meditations, I have added certayne Observations, upon your more solemne festiball dayes.

The explicit nature of its contents might explain why this manuscript was never printed. It could be the case that this manuscript might have been used by Catholics in their private devotions - obviously, by those within the Dorset circle. After his brushes with the Protestant party under Abbot, the changing situation after 1626 must have encouraged Mabbe to gradually come out into the open, and print two other translations from Catholic authors in the years that followed, i.e. the Devout Contemplations of 1629 and Santa Marías Christian Policie in 1632-both volumes published on both sides of the peace treaty with Spain of 1630. Both were preceded by successful translations of Spanish prose fiction-The Rogue in 1622, and The Spanish Bawd in 1631-as if Mabbe needed the credit of his abilities as a translator of recreational literature to justify the publication of explicitly doctrinal texts.

After this, Mabbe's last published translation was a partial rendering of Cervantes's Novelas ejemplares (Madrid, 1613), his Exemplarie Novels; in Sixe Books (London: John Dawson, 1640; STC (2nd ed.) / 4914). The volume was dedicated to Susanna Strangways, wife of Gyles Strangways, the son and heir of Sir John Strangways. This translation, written in retirement, put an end to Mabbe's career. He had left Oxford in 1633, and subsequently moved in with the Strangways-his patrons of more than 30 years—at Abbotsbury, Dorset, where he probably died ca. 1642. Anthony á Wood says he is buried there too. ${ }^{51}$

\footnotetext{
${ }^{51}$ Anthony à Wood, Athenae Oxonienses, new edn, 3.53-4.During his final years Mabbe appears to have been working on another translation (Medicina Hispánica), which was unfinished at the time of his death: see Yamamoto-Wilson, 2012, p. 325, n. 27.
} 